\title{
Sources, Bioavailability And Adequacy of Zinc Intake Among Rural- Resident Men In Malawi
}

Lydia Pakira ( $\square$ lydiapakira001.Ip@gmail.com )

Kamuzu Central Hospital https://orcid.org/0000-0001-9650-7129

Alexander Kalimbira

Lilongwe University of Agriculture and Natural Resources

\section{Research}

Keywords: Bioavailability, Malawi, men, zinc deficiency, 24-hour recall

Posted Date: September 8th, 2021

DOI: https://doi.org/10.21203/rs.3.rs-829176/v1

License: (c) (i) This work is licensed under a Creative Commons Attribution 4.0 International License. Read Full License 


\section{Abstract}

Background: Zinc deficiency (ZnD), measured using serum zinc ( $\mathrm{Zn}$ ) prevails in 66\% of 20-54 year-old men in Malawi, and is higher than that of other demographic groups. We conducted this study to identify local plant and animal sources of $Z n$; to determine the frequency of intake of $Z n$ rich foods; and, to assess the bioavailability of $\mathrm{Zn}$ in the food sources.

Methods: We employed a descriptive cross-sectional study of 20-54 year-old men $(n=101)$ who are residents of a rural area of Lilongwe district in central Malawi. Dietary assessment was done using a food frequency questionnaire and 24-hour dietary recall. Dietary adequacy was assessed using modified NutriSurvey 2007. Zinc bioavailability was estimated using Murphy's model of algorithm based on FAO/WHO Zn bioavailability factors.

Results: Only $20.3 \%$ of the participants were knowledgeable of Zn, and mostly cited rice, cassava, sweet potato, milk and fish as sources of Zn. Degermed-dehulled hard porridge (locally called nsima) (53.5\%), small fish (30.7\%), mangoes (69.3\%), groundnuts (20.8\%), pumpkin leaves (65.3\%) and sunflower oil (24.8\%) were the most frequently consumed foods. Slightly over one third (36.6\%) of the participants met the recommended dietary allowance for $\mathrm{Zn}$ (mean intake of $14.4 \pm 14 \mathrm{mg}$ ), but $\otimes 1 \%$ consumed $\mathrm{Zn}$ that was bioavailable (mean $2.2 \pm 2.5 \mathrm{mg}$ ).

Conclusion: Habitual intake of plant-based diets with poorly bioavailable Zn was widespread among men in this rural population in Malawi, which led to inadequate dietary $\mathrm{Zn}$ intake. Food systems-based operational research should be conducted to understand barriers and facilitators of adequate intake of bioavailable $\mathrm{Zn}$ in rural areas of Malawi.

\section{Introduction}

Zinc ( $\mathrm{Zn})$ is a trace element that is required as a cofactor by more than 100 enzymes in the body [1], where it plays catalytic [2], structural [3] and regulatory roles [4], in addition to antioxidant and anti-inflammatory effects in many organisms [5]. It is important to maintain adequate $Z n$ in the body because $\mathrm{Zn}$ deficiency $(\mathrm{ZnD})$ is associated with malfunction of the body, and is a factor in the risk of chronic diseases such as diabetes, cardiovascular, and liver diseases [6]. ZnD can be as a result of dietary inadequacies [7], diseases like diarrhoea that lead to excessive losses or impaired utilization [8], and physiological needs that increase Zn requirements in the body [9]. Dietary intake of $\mathrm{Zn}$ is affected by the amount of $\mathrm{Zn}$ available for absorption. Phytic acid, which is the storage form of phosphorus in plants, has an inhibitory effect on $\mathrm{Zn}$ absorption, hence it is a major factor in determining bioavailability of Zn from plant sources [10].

It has been estimated that $17.3 \%$ of the world's population has inadequate $Z n$ intake, more so in Africa (23.9\%) [11], with deficiency risk estimated at $40 \%$ [12]. Malawi is a Zn deficient country, where prevalence (measured using serum Zn concentration) ranges from $60 \%$ in children under the age of 5 years, to $66 \%$ in 20-54 year-old men [13]. Previous localised studies had already shown that ZnD was likely to be widespread in Malawi $[14,15,16]$. Owing to the consequences of $\mathrm{ZnD}$ such as impaired growth and development, susceptibility to diarrheal and respiratory infections [8], and some chronic diseases [17] including elements of the metabolic syndrome [18], public health nutrition has interest to improve population Zn status. Therefore, we undertook this localized study in a rural area in central Malawi, to get insights into men's dietary practices that may contribute to their vulnerability to high prevalence of ZnD. Specifically, we aimed to identify local plant and animal sources of Zn; determine frequency of intake of Zn-rich foods; and, assess bioavailability of Zn from the food sources.

\section{Methods}

\subsection{Study design}

We designed a descriptive cross-sectional study to recruit 101 men aged 20-54 years who were residents of Traditional Authority (TA) Chiseka, a rural area of Lilongwe district in central Malawi. Specifically, we randomly selected Mkwinda Group Village Head, which is a cluster of villages under TA Chiseka. According to the 2018 Malawi Population and Housing Census, TA Chiseka had 63,045 men and women aged $\geq 20$ years [19]. Sample size was calculated using an online calculator embedded in OpenEpi version 3.01 [20]. We used the population of adults of 63,045, design effect of 1 , absolute precision (confidence interval) of 5\%, to calculate a representative sample of 104 men, of which 101 participated, representing a response rate of $97.1 \%$.

Mkwinda had 8 villages, out of which we randomly selected 4 villages from which the study sample was drawn. Village registers were used to draw an eligible list of men, out of whom we selected eligible participants based on the following inclusion criteria: age of 20-54 years, residence in the area for not less than 2 years, in apparent good health, and giving informed consent to participate. The study protocol was approved by the National Health Sciences Research Committee in Malawi, whose approval number was 2200 . We received permission to conduct the study in the area from Traditional Authority Chiseka, while informed verbal consent was obtained from every participant. A team of six trained research assistants administered a pre-tested structured questionnaire to the participants through face-to-face interviews in each participant's own home.

\subsection{Dietary assessment}


A food frequency questionnaire (FFQ) was administered to the study subjects to assess their usual food intake. The FFQ consisted of 63 foods that were commonly consumed in the area containing Zn, and had a part for recording how frequently each food item was consumed. The FFQ was used to determine the frequency of dietary intake. A 24-hour recall was used to collect data on actual food intake [21]. This required respondents to recall all foods that were consumed the previous day. The type of food, the time that it was consumed, and the amount of food consumed was estimated.

\subsection{Data analysis}

Data were entered and analyzed using IBM SPSS Statistics version 21.0 (IBM Corporation, Armonk, New York, USA) to generate descriptive statistics (frequencies, percentages and means). We modified NutriSurvey 2007 (www.nutrisurvey.de) to include some Malawian foods that were available in the study area based on nutritive values contained in the Malawian Food Composition Table 2019 [22]). The modified NutriSurvey 2007 was used to analyze nutrient intake of individuals collected through the 24-hour dietary recall to estimate the amount of Zn consumed. We calculated estimated energy and Zn intake, whose values were extracted into Microsoft Excel 2013 (Microsoft Corporation, Santa Rosa, California, USA), and exported to IBM SPSS Statistics 21 for descriptive analysis. Bioavailability was estimated using Murphy's model of algorithm in which each diet was given a $\mathrm{Zn}$ availability factor according to FAO/WHO classification system, and multiplied by the amount of Zn in the diet to get an estimate of bioavailable Zn [21].

\section{Results}

\subsection{Characteristics of study participants}

Data were collected from 101 apparently healthy adult men aged 20-54 years. The mean age of the participants was 38 years. A majority of the participants were married (87.1\%), $64.4 \%$ were farmers, $69.3 \%$ had attained up to primary school education, and $79.2 \%$ of the participants were Christians. The demographic characteristics of the study population are presented in Table 1.

Table 1: Demographic Characteristics 


\begin{tabular}{llll} 
Demographics & $\mathrm{n}$ & $\%$ & Mean \pm SD \\
\hline Age (years) & 101 & $37.8 \pm 10.5$
\end{tabular}

\begin{tabular}{llll} 
Marital status & Single & 9 & 8.9 \\
\hline Married & 88 & 87.1 \\
Widowed & 2 & 2.0 \\
\hline Separated & 1 & 1.0 \\
\hline Polygamous marriage & 1 & 1.0
\end{tabular}

\begin{tabular}{llll}
\hline Occupation & Farmer & 65 & 64.4 \\
\hline Formal employment & 7 & 6.9 \\
\hline Vocational skills & 11 & 10.9 \\
\hline Business & 14 & 13.9 \\
\hline Unemployed & 4 & 4.0
\end{tabular}

\begin{tabular}{llll}
\hline Level of education & Primary school & 70 & 69.3 \\
\hline Secondary school & 17 & 16.8 \\
\hline Tertiary education & 1 & 1 \\
\hline None & 13 & 12.9
\end{tabular}

\begin{tabular}{llll}
\hline Religion & Christianity & 80 & 79.2 \\
\hline African & 10 & 9.9 \\
\hline Muslim & 7 & 6.9 \\
\hline None & 4 & 4
\end{tabular}

\subsection{Knowledge of $\mathrm{Zn}$}

Only $20.3 \%$ of the respondents had ever heard of $\mathrm{Zn}$, with only $11.9 \%$ knowing the dietary sources. When probed more to mention the sources of Zn they knew, most of them (70\%) were able to mention plants but could not be specific on which plants contain Zn. Some (20\%) were able to mention the plant sources like rice, cassava and sweet potato. Few of them (10\%) mentioned animal sources like milk and fish. However, none of the respondents mentioned both the plant and animal sources of $\mathrm{Zn}$. To some respondents their knowledge of $\mathrm{Zn}$ was referred to a metal as they mentioned metal as a source of $\mathrm{Zn}$. It was observed that amongst the $20.3 \%$ of the participants who ever heard of $\mathrm{Zn}$, only $17.8 \%$ knew about the benefits of $\mathrm{Zn}$ to their bodies and $10.9 \%$ knew about the consequences that may arise due to $\mathrm{ZnD}$.

\subsection{Frequency of intake of $\mathrm{Zn}$ rich foods}

Some foods were consumed frequently due to seasonal availability for example, mango fruits and pumpkin leaves. It was evident that hard porridge (nsima) made from dehulled-degermed maize flour commonly known as gramil (53.5\%) was the most consumed staple among the participants, with sweet potato being the least consumed staple (66.3\% of the participants did not consume sweet potato in a month). Whole grain maize flour was also consumed daily by $36.6 \%$ of the participants, while rice was consumed at least once per week by $25.7 \%$ of the participants.

Small fish (30.7\%) were the most frequently consumed animal source food whilst insects were the least consumed since $75.2 \%$ of the respondents reported of never having eaten any in the past month. Only $28.7 \%$ of the respondents reported consuming beef once in a month. In addition, poultry was consumed once a week by $21.8 \%$ of the participants. In terms of legumes, groundnuts (20.8\%) was the most frequently consumed legume, whereas $85.1 \%$ of the respondents reported of not consuming any chick peas in the past month. Beans (26.7\%) were consumed often at $4-6$ times a week. Results also revealed that $93.1 \%$ of the participants used tomato in their daily meal and pumpkin leaves (65.3\%) being the most frequently 
consumed vegetable and carrots the least consumed vegetable, with $65.3 \%$ of the participant reporting that they had never consumed it in a month. Cabbage was highly consumed at 4-6 times a week (22.8\%).

A bigger proportion of the participants consumed mangoes daily (69.3\%) and apple was the least consumed fruit (15.3\%). Fruit consumption among the participants was generally low. Only $24.8 \%$ of the participants used cooking oil made from sunflower every day. Groundnut flour was reported to be consumed $4-6$ times a week by $29.7 \%$ of the respondents. The results for the consumption of foods containing $\mathrm{Zn}$ are shown in Table 2 
Table 2

Frequency of consuming Zn-containing foods

\begin{tabular}{|c|c|c|c|c|c|c|c|c|c|c|c|c|c|c|c|c|}
\hline \multirow[t]{3}{*}{ Food type } & \multicolumn{16}{|c|}{ Food Frequency } \\
\hline & \multicolumn{2}{|c|}{ Daily } & \multicolumn{2}{|c|}{$\begin{array}{l}2-3 \\
\text { times/week }\end{array}$} & \multicolumn{2}{|c|}{$\begin{array}{l}4-6 \\
\text { times/week }\end{array}$} & \multicolumn{2}{|c|}{ Once/week } & \multicolumn{2}{|c|}{ Once/3weeks } & \multicolumn{2}{|c|}{ Once/month } & \multicolumn{2}{|c|}{$\begin{array}{l}2-3 \\
\text { times/month }\end{array}$} & \multicolumn{2}{|c|}{ Rarely/never } \\
\hline & $\mathbf{N}$ & $\%$ & $\mathbf{N}$ & $\%$ & $\mathbf{N}$ & $\%$ & $\mathbf{n}$ & $\%$ & $\mathrm{n}$ & $\%$ & $\mathbf{N}$ & $\%$ & $\mathrm{n}$ & $\%$ & $\mathbf{n}$ & $\%$ \\
\hline Staples & 37 & 36.6 & 14 & 13.9 & 7 & 6.9 & 9 & 8.9 & 2 & 2.0 & 6 & 5.9 & 0 & 0 & 26 & 25.7 \\
\hline \multicolumn{17}{|l|}{$\begin{array}{l}\text { Whole grain maize } \\
\text { flour }\end{array}$} \\
\hline $\begin{array}{l}\text { Dehulled- } \\
\text { degermed maize } \\
\text { flour }\end{array}$ & 54 & 53.5 & 12 & 11.9 & 5 & 5.0 & 6 & 5.9 & 1 & 1.0 & 6 & 5.9 & 1 & 1.0 & 16 & 15.8 \\
\hline $\begin{array}{l}\text { Fermented refined } \\
\text { maize flour }\end{array}$ & 10 & 9.9 & 2 & 2.0 & 5 & 5.0 & 10 & 9.9 & 7 & 6.9 & 15 & 14.9 & 1 & 1.0 & 51 & 50.5 \\
\hline Roasted Maize & 17 & 16.8 & 27 & 26.7 & 6 & 5.9 & 17 & 16.8 & 4 & 4.0 & 11 & 10.9 & 3 & 3.0 & 16 & 15.8 \\
\hline Boiled maize & 13 & 12.9 & 31 & 30.7 & 8 & 7.9 & 14 & 13.9 & 7 & 6.9 & 10 & 9.9 & 3 & 3.0 & 15 & 14.9 \\
\hline Rice & 2 & 2.0 & 21 & 20.8 & 5 & 5.0 & 26 & 25.7 & 8 & 7.9 & 24 & 23.8 & 2 & 2.0 & 13 & 12.9 \\
\hline Bread & 15 & 14.9 & 18 & 17.8 & 13 & 12.9 & 11 & 10.9 & 4 & 4.0 & 11 & 10.9 & 3 & 3.0 & 26 & 25.7 \\
\hline African cake & 15 & 14.9 & 11 & 10.9 & 3 & 3.0 & 11 & 10.9 & 3 & 3.0 & 10 & 9.9 & 3 & 3.0 & 45 & 44.6 \\
\hline Doughnuts & 25 & 24. & 27 & 26.7 & 11 & 10.9 & 16 & 15.8 & 1 & 1.0 & 5 & 5.0 & 3 & 3.0 & 13 & 12.9 \\
\hline Banana flitters & 13 & 12.9 & 29 & 28.7 & 14 & 13.9 & 9 & 8.9 & 5 & 5.0 & 6 & 5.9 & 3 & 3.0 & 22 & 21.8 \\
\hline Raw cassava & 19 & 18.8 & 27 & 26.7 & 14 & 13.9 & 14 & 13.9 & 2 & 2.0 & 7 & 6.9 & 4 & 4.0 & 14 & 13.9 \\
\hline Boiled cassava & 13 & 12.9 & 24 & 23.8 & 11 & 10.9 & 18 & 17.8 & 6 & 5.9 & 10 & 9,9 & 1 & 1.0 & 18 & 17.8 \\
\hline Roasted & 8 & 7.9 & 11 & 10.9 & 3 & 3.0 & 10 & 9.9 & 2 & 2.0 & 3 & 3.0 & 0 & 0 & 64 & 63.4 \\
\hline Boiled-Irish potato & 1 & 1.0 & 14 & 13.9 & 9 & 8.9 & 11 & 10.9 & 2 & 2.0 & 13 & 12.9 & 1 & 1.0 & 50 & 48.5 \\
\hline Chips & 18 & 17.8 & 27 & 26.7 & 10 & 9.9 & 17 & 16.8 & 4 & 4.0 & 10 & 9.9 & 4 & 4.0 & 11 & 10.9 \\
\hline $\begin{array}{l}\text { Boiled sweet } \\
\text { potato }\end{array}$ & 5 & 5.0 & 13 & 12.9 & 7 & 6.9 & 9 & 8.9 & 2 & 2.0 & 8 & 7.9 & 1 & 1.0 & 56 & 55.4 \\
\hline $\begin{array}{l}\text { Roasted sweet } \\
\text { potato }\end{array}$ & 1 & 1.0 & 9 & 8.9 & 8 & 7.9 & 7 & 6.9 & 1 & 1.0 & 7 & 6.9 & 1 & 1.0 & 67 & 66.3 \\
\hline Sweet beer & 22 & 21.8 & 28 & 27.7 & 11 & 10.9 & 14 & 13.9 & 4 & 4.0 & 6 & 5.9 & 5 & 5.0 & 11 & 10.9 \\
\hline \multicolumn{17}{|l|}{ Animal sources } \\
\hline Beef & 0 & 0 & 2 & 2.0 & 0 & 0 & 11 & 10.9 & 1 & 1.0 & 29 & 28.7 & 1 & 1.0 & 57 & 56.4 \\
\hline Goat meat & 3 & 3.0 & 20 & 19.8 & 3 & 3.0 & 16 & 15.8 & 7 & 6.9 & 23 & 22.8 & 1 & 1.0 & 39 & 38.6 \\
\hline Pork & 4 & 4.0 & 22 & 21.8 & 6 & 5.9 & 17 & 16.8 & 5 & 5.0 & 7 & 6.9 & 1 & 1.0 & 39 & 38.6 \\
\hline Poultry & 10 & 9.9 & 18 & 17.8 & 12 & 11.9 & 22 & 21.8 & 5 & 5.0 & 15 & 14.9 & 7 & 6.9 & 12 & 11.9 \\
\hline Tilapia & 1 & 1.0 & 9 & 8.9 & 4 & 4.0 & 3 & 3.0 & 4 & 4.0 & 20 & 19.8 & 0 & 0 & 60 & 59.4 \\
\hline $\begin{array}{l}\text { Copadichromis } \\
\text { inornatus }\end{array}$ & 5 & 5.0 & 31 & 30.7 & 11 & 10.9 & 11 & 10.9 & 4 & 4.0 & 10 & 9.9 & 4 & 4.0 & 25 & 24.5 \\
\hline Catfish & 1 & 1.0 & 1 & 1.0 & 6 & 5.9 & 4 & 4.0 & 4 & 4.0 & 17 & 16.8 & 0 & 0 & 68 & 67.3 \\
\hline Lake sardine & 13 & 12.9 & 41 & 40.6 & 15 & 14.9 & 11 & 10.9 & 3 & 3.0 & 5 & 5.0 & 0 & 0 & 13 & 12.9 \\
\hline Small fish & 31 & 30.7 & 27 & 26.7 & 19 & 18.8 & 8 & 7.9 & 2 & 2.0 & 2 & 2.0 & 0 & 0 & 9 & 8.9 \\
\hline $\begin{array}{l}\text { Rhamphochromis } \\
\text { esox }\end{array}$ & 1 & 1.0 & 10 & 9.9 & 8 & 7.9 & 15 & 14.9 & 9 & 8.9 & 14 & 13.9 & 1 & 1.0 & 43 & 42.6 \\
\hline $\begin{array}{l}\text { Barbus } \\
\text { paludinosus }\end{array}$ & 3 & 3.0 & 18 & 17.8 & 9 & 8.9 & 19 & 18.8 & 12 & 11.9 & 9 & 8.9 & 2 & 2.0 & 29 & 28.7 \\
\hline
\end{tabular}




\begin{tabular}{|c|c|c|c|c|c|c|c|c|c|c|c|c|c|c|c|c|}
\hline \multirow{3}{*}{$\begin{array}{l}\text { Food type } \\
\text { Milk }\end{array}$} & \multicolumn{16}{|c|}{ Food Frequency } \\
\hline & \multicolumn{2}{|c|}{ Daily } & \multicolumn{2}{|c|}{$\begin{array}{l}2-3 \\
\text { times/week }\end{array}$} & \multicolumn{2}{|c|}{$\begin{array}{l}4-6 \\
\text { times/week }\end{array}$} & \multicolumn{2}{|c|}{ Once/week } & \multicolumn{2}{|c|}{ Once/3weeks } & \multicolumn{2}{|c|}{ Once/month } & \multicolumn{2}{|c|}{$\begin{array}{l}2-3 \\
\text { times/month }\end{array}$} & \multicolumn{2}{|c|}{ Rarely/never } \\
\hline & 12 & 11.9 & 6 & 5.9 & 12 & 11.9 & 19 & 18.8 & 8 & 7.9 & 13 & 12.9 & 0 & 0 & 31 & 30.7 \\
\hline Eggs & 8 & 7.9 & 17 & 16.8 & 19 & 18.8 & 13 & 12.9 & 5 & 5.0 & 12 & 11.9 & 5 & 5.0 & 22 & 21.8 \\
\hline Liver & 1 & 1.0 & 5 & 5.0 & 4 & 4.0 & 7 & 6.9 & 6 & 5.9 & 11 & 10.9 & 1 & 1.0 & 66 & 65.3 \\
\hline Insects & 2 & 2.0 & 5 & 5.0 & 2 & 2.0 & 3 & 3.0 & 5 & 5.0 & 8 & 7.9 & 0 & 0 & 76 & 75.2 \\
\hline \multicolumn{17}{|l|}{ Fruits } \\
\hline Pineapple & 0 & 0 & 2 & 2.0 & 3 & 3.0 & 5 & 5.0 & 0 & 0 & 14 & 13.9 & 1 & 1.0 & 73 & 72.3 \\
\hline Loquat & 4 & 4.0 & 0 & 0 & 5 & 5.0 & 7 & 6.9 & 3 & 3.0 & 10 & 9.9 & 0 & 0 & 72 & 71.3 \\
\hline Mango & 70 & 69.3 & 18 & 17.8 & 10 & 9.9 & 2 & 2.0 & 0 & 0 & 0 & 0 & 0 & 0 & 1 & 1.0 \\
\hline Paw paw & 2 & 2.0 & 10 & 9.9 & 11 & 10.9 & 6 & 5.9 & 7 & 6.9 & 11 & 10.9 & 2 & 2.0 & 52 & 51.5 \\
\hline Apple & 0 & 0 & 0 & 0 & 3 & 3.0 & 3 & 3.0 & 1 & 1.0 & 9 & 8.9 & 0 & 0 & 85 & 84.2 \\
\hline Baobab & 0 & 0 & 1 & 1.0 & 7 & 6.9 & 5 & 5.0 & 2 & 2.0 & 9 & 8.9 & 1 & 1.0 & 76 & 75.2 \\
\hline \multicolumn{17}{|l|}{ Vegetables } \\
\hline Cabbage & 7 & 6.9 & 5 & 5.0 & 23 & 22.8 & 13 & 12.9 & 10 & 9.9 & 20 & 19.8 & 5 & 5.0 & 18 & 17.8 \\
\hline Carrots & 0 & 0 & 1 & 1.0 & 9 & 8.9 & 6 & 5.9 & 3 & 3.0 & 14 & 13.9 & 2 & 2.0 & 66 & 65.3 \\
\hline Cassava leaves & 17 & 16.8 & 7 & 6.9 & 10 & 9.9 & 14 & 13.9 & 4 & 4.0 & 11 & 10.9 & 2 & 2.0 & 35 & 34.7 \\
\hline Green beans & 3 & 3.0 & 12 & 11.9 & 16 & 15.8 & 12 & 11.9 & 4 & 4.0 & 10 & 9.9 & 0 & 0 & 42 & 41.2 \\
\hline Okra & 17 & 16.8 & 14 & 13.9 & 15 & 14.9 & 19 & 18.8 & 4 & 4.0 & 5 & 5.0 & 1 & 1.0 & 26 & 25.7 \\
\hline Black jack & 15 & 14.9 & 21 & 20.8 & 26 & 25.7 & 19 & 18.8 & 4 & 4.0 & 6 & 5.9 & 4 & 4.0 & 6 & 5.9 \\
\hline Amaranth & 17 & 16.8 & 29 & 28.7 & 23 & 22.8 & 13 & 12.9 & 2 & 2.0 & 9 & 8.9 & 2 & 2.0 & 6 & 5.9 \\
\hline Chinese & 17 & 16.8 & 20 & 19.8 & 20 & 19.8 & 14 & 13.9 & 7 & 6.9 & 5 & 5.0 & 2 & 2.0 & 16 & 15.8 \\
\hline Tomato & 94 & 93.1 & 5 & 5.0 & 2 & 2.0 & 0 & 0 & 0 & 0 & 0 & 0 & 0 & 0 & 0 & 0 \\
\hline $\begin{array}{l}\text { Cat's whiskers } \\
\text { leaves }\end{array}$ & 19 & 18.8 & 8 & 7.9 & 13 & 12.9 & 4 & 4.0 & 2 & 2.0 & 10 & 9.9 & 0 & 0 & 45 & 44.6 \\
\hline Jewsmallowleaves & 20 & 19.8 & 21 & 20.8 & 25 & 24.8 & 10 & 9.9 & 3 & 3.0 & 4 & 4.0 & 2 & 2.0 & 16 & 15.8 \\
\hline Pumpkin leaves & 66 & 65.3 & 18 & 17.8 & 15 & 14.9 & 2 & 2.0 & 0 & 0 & 0 & 0 & 0 & 0 & 0 & 0 \\
\hline Rape & 6 & 5.9 & 18 & 17.8 & 27 & 26.7 & 16 & 15.8 & 4 & 4.0 & 8 & 7.9 & 0 & 0 & 22 & 21.8 \\
\hline Roselle leaves & 15 & 14.9 & 7 & 6.9 & 17 & 16.8 & 8 & 7.9 & 10 & 9.9 & 12 & 11.9 & 1 & 1.0 & 31 & 30.7 \\
\hline \multicolumn{17}{|l|}{ Legumes } \\
\hline Beans & 5 & 5.0 & 23 & 22.8 & 27 & 26.7 & 19 & 18.8 & 4 & 4.0 & 9 & 8.9 & 2 & 2.0 & 12 & 11.9 \\
\hline Cowpeas & 2 & 2.0 & 13 & 12.9 & 22 & 21.8 & 13 & 12.9 & 3 & 3.0 & 23 & 22.8 & 1 & 1.0 & 12 & 11.9 \\
\hline Pigeon pea & 1 & 1.0 & 4 & 4.0 & 8 & 7.9 & 8 & 7.9 & 3 & 3.0 & 23 & 22.8 & 1 & 1.0 & 24 & 23.8 \\
\hline Bambara nuts & 0 & 0 & 2 & 2.0 & 11 & 10.9 & 6 & 5.9 & 6 & 5.9 & 17 & 16.8 & 0 & 0 & 59 & 58.4 \\
\hline Groundnuts & 21 & 20.8 & 23 & 22.8 & 22 & 21.8 & 12 & 11.9 & 4 & 4.0 & 5 & 5.0 & 1 & 1.0 & 13 & 12.9 \\
\hline Soy beans & 15 & 14.9 & 21 & 20.8 & 14 & 13.9 & 13 & 12.9 & 6 & 5.9 & 8 & 7.9 & 1 & 1.0 & 23 & 22.8 \\
\hline Chick pea & 0 & 0 & 2 & 2.0 & 2 & 2.0 & 1 & 1.0 & 4 & 4.0 & 6 & 5.9 & 0 & 0 & 86 & 85.1 \\
\hline \multicolumn{17}{|l|}{ Fats and oils } \\
\hline G/nut flour & 14 & 13.9 & 25 & 24.8 & 30 & 29.7 & 15 & 14.9 & 5 & 5.0 & 1 & 1.0 & 5 & 5.0 & 6 & 5.9 \\
\hline Sunflower & 25 & 24.8 & 16 & 15.8 & 13 & 12.9 & 10 & 9.9 & 5 & 5.0 & 3 & 3.0 & 0 & 0 & 3 & 3.0 \\
\hline
\end{tabular}




\begin{tabular}{|c|c|c|c|c|c|c|c|c|c|c|c|c|c|c|c|c|}
\hline \multirow[t]{2}{*}{ Food type } & \multicolumn{16}{|c|}{ Food Frequency } \\
\hline & \multicolumn{2}{|c|}{ Daily } & \multicolumn{2}{|c|}{$\begin{array}{l}2-3 \\
\text { times/week }\end{array}$} & \multicolumn{2}{|c|}{$\begin{array}{l}4-6 \\
\text { times/week }\end{array}$} & \multicolumn{2}{|c|}{ Once/week } & \multicolumn{2}{|c|}{ Once/3weeks } & \multicolumn{2}{|c|}{ Once/month } & \multicolumn{2}{|c|}{$\begin{array}{l}2-3 \\
\text { times/month }\end{array}$} & \multicolumn{2}{|c|}{ Rarely/neve } \\
\hline Pumpkin seed & 10 & 9.9 & 5 & 5.0 & 8 & 7.9 & 2 & 2.0 & 2 & 2.0 & 11 & 10.9 & 0 & 0 & 63 & 62.4 \\
\hline Sesame & 0 & 0 & 0 & 0 & 2 & 2.0 & 3 & 3.0 & 2 & 2.0 & 3 & 3.0 & 0 & 0 & 91 & 90.1 \\
\hline
\end{tabular}

\subsection{Energy, iron and zinc intake}

Mean energy intake of the participants was $1470 \pm 706 \mathrm{kcal}$, which fell below the estimated energy requirement of $2200 \mathrm{kcal} / \mathrm{day}$ for males. Only $14.85 \%$ of the participants met the daily energy requirement. The mean iron intake of the participants was $22.7 \mathrm{mg}$, which is almost three times higher than the recommended dietary requirements of $8 \mathrm{mg} /$ day in men. $60.3 \%$ of the participants met their Recommended Dietary Allowance (RDA) for iron. The mean Zn intake was $14.4 \pm 14.1 \mathrm{mg}$, which was above the recommended dietary allowance of $11 \mathrm{mg}$ for adult men. Only $36.6 \%$ of the participants met their RDA for $\mathrm{Zn}$ but $<1 \%$ had $\mathrm{Zn}$ which was available to the body with mean $2.2 \pm 2.6 \mathrm{mg}$. It revealed that only $11.8 \%$ of the diets had Zn which was highly bioavailable, while $41.2 \%$ had moderately bioavailable Zn and $46.5 \%$ had low Zn bioavailability. Low Zn bioavailability diets are those that have a phytate: $\mathrm{Zn}$ molar ratio above 15 , in which only $15 \%$ of the $\mathrm{Zn}$ is absorbed, moderate bioavailable $\mathrm{Zn}$ diets are those with phytate: $\mathrm{Zn}$ molar ratio of $5-15$ and about $30 \%$ of $\mathrm{Zn}$ is absorbed and high $\mathrm{Zn}$ bioavailability diet are those with phytate: $\mathrm{Zn}$ molar ratio of $<5$ and $50 \%$ of $\mathrm{Zn}$ is absorbed.

\section{Discussion}

\subsection{Zinc intake}

Evidence shows that a majority of the participants (53.5\%) ate dehulled-degermed maize flour as their main staple food in which a certain amount of phytic acid (PA) is removed, which improves bioavailability of $\mathrm{Zn}$. The removal of maize bran reduces the amount of phytic acid to $526.5 \mathrm{mg} / 100 \mathrm{~g}$ from $743 \mathrm{mg} / 100 \mathrm{~g}$ of whole grain maize flour [23]. This method removes a certain amount of PA but the best probable method of improving bioavailability of $\mathrm{Zn}$ in maize flour is through soaking, which reduces PA levels to $161.5 \mathrm{mg} / 100 \mathrm{~g}$ in maize flour which has been soaked for three days. However, the consumption of dehulled-degermed maize flour could not improve the uptake of $\mathrm{Zn}$ as compared to whole grain maize flour, rice and wheat flour because some $\mathrm{Zn}$ is lost during processing. Zn from animal source foods is found in credible amounts and readily available for the body, some of the participants (30.7\%) consumed fish in their daily meals and $19.8 \%$ consumed goat meat at least 2 to 3 times in a week. This showed that a lot of people did not consume meat frequently and their diets were more plant-based, which indicates consumption of more PA, thereby reducing the amount of Zn absorbed. Rural diets in developing countries including Malawi are predominantly plant-based; consumption of animal-protein foods such as meat, poultry and fish is often small because of economic, cultural and/or religious constraints [21]. As a result, the amount of $\mathrm{Zn}$ available for absorption from such diets is low, and is probably the primary cause of $\mathrm{ZnD}$.

\subsection{Bioavailability of Zn}

Dietary components of the food are known to modify the bioavailability of Zn, some enhance absorption and others inhibit absorption [21]. Organic acids such as lactic and citric acids may enhance the absorption of Zn, while PA and calcium (Ca) inhibit the absorption of Zn. However, the amount of $\mathrm{Ca}$ in most plant-based diet is too low to have an inhibitory effect on $\mathrm{Zn}$ [9]. A consideration between intake and absorption is important, because although some intakes of $Z n$ may be acceptable, the level of phytate inhibition in the diet may mean inadequate amounts of $Z n$ is absorbed. The risk of ZnD was estimated to be at $40 \%$ in African countries despite having a mean supply of $12.9 \mathrm{mg} / \mathrm{capita} / \mathrm{day}$ which was above the RDA [12]. Cereals, nuts and legumes contributed a high amount of Zn consumption to the populations. However, the risk of ZnD in a normal mean supply population meant that, the amount that was absorbed in the intestines was probably reduced from what was consumed. It is also evident from the study that the amount of Zn that was ingested from the foods was not available for absorption, which may contribute to the high prevalence of Zn deficiency among adult men. Even though the amount of iron seems to be high, it is also likely that little was absorbed because $\mathrm{Zn}$ and iron may be affected by many of the same dietary factors including phytate [24]. Consumption of food with high phytic acid is associated with low absorption of $\mathrm{Zn}$ [25]. A study showed that consumption of low phytic acid maize contributed to an increased absorption of $\mathrm{Zn}$ as compared to local polenta maize which had phytic acid: $Z n$ ratio of $36: 1$. Even though the PA: Zn ratio was 17:1 which is above 15 , there was an improvement in the absorption of $\mathrm{Zn}$ in low PA maize.

\section{Conclusions}

The most frequently consumed Zn-containing foods among men in this rural central Malawian population were degermed-dehulled maize thick porridge, pumpkin leaves, groundnuts, mango and fish. Slightly over one third of the participants met the recommended dietary allowance for Zn, but $\otimes 1 \%$ consumed $\mathrm{Zn}$ that was bioavailable. Adding to the pool of knowledge which has consistently shown that habitual intake of plant-based

Page $8 / 10$ 
diets with poorly bioavailable Zn leads to inadequate dietary Zn, our study has demonstrated that in addition to children, rural resident adult Malawian men are equally affected. Food systems-based operational research should be conducted to understand barriers and facilitators of adequate intake of bioavailable $\mathrm{Zn}$ in rural areas of Malawi.

\section{Declarations}

\section{Ethical approval and consent}

Ethical approval was granted by the National Health Sciences Research Committee (NHSRC) with an approval number 2200. Verbal and written informed consent were obtained from the authorities (T/A Chiseka and SGV Mkwinda) and participants also gave written and verbal informed consent prior to interviews. Participation in the study was voluntary and participants were allowed to withdraw at any time of the study.

\section{Publication consent}

Verbal and written consent for publication from participants was obtained during data collection.

\section{Availability of data materials}

The datasets used and/or analysed during this study are available from the corresponding author on reasonable request.

\section{Competing interest}

The authors declare no competing interest.

\section{Authors contribution}

AAK conceived the study. AAK and LP designed the study. LP collected, entered and analysed the data and drafted the manuscript. AAK revised the manuscript for intellectual content. AAK and LP gave final approval of the published version. Both authors take responsibility for appropriate portions of the content.

\section{Funding}

This study was supported by an undergraduate research grant awarded to LP by the Lilongwe University of Agriculture and Natural Resources (LUANAR).

\section{Acknowledgements}

Special thanks should go to all the respondents for their participation in the study.

\section{Author's information}

LP was an undergraduate student in department of Human Nutrition and Health, Faculty of Food and Human Sciences at LUANAR. AAK is the head of department of Human Nutrition and Health, Faculty of Food and Human Sciences

\section{References}

1. Whitney E, Rolfes SR. Understanding Nutrition;12th edition, Cengage Learning: Wadsworth, USA, 2011.

2. Vallee BL, Falchuk KH. The biochemical basis of zinc physiology. Physiol Rev. 1993;73(1):79-118. DOI:10.1152/physrev.1993.73.1.79.

3. Mangelsdorf DJ, Thummel C, Beato M, Herrlich P, Schütz G, Umesono K, Blumberg B, Kastner P, Mark M, Chambon P, Evans RM. The nuclear receptor superfamily: the second decade. Cell. 1995;83(6):835. DOI:10.1016/0092-8674(95)90199-x.

4. King JC, Cousins RJ. Zinc. In: Ross AC, Caballero B, Cousins RJ, Tucker KL, Ziegler TR eds. Modern Nutrition in Health and Disease; 11 th edition, Baltimore: Lippincott Williams and Wilkins, 2014.

5. Jung SK, Kim M, Lee YH, Shin DH, Shin M, Chun BY, Choi BY. Lower zinc bioavailability may be related to higher risk of subclinical atherosclerosis in Korean adults. PLoS One. 2013;8:11:1-11. DOI:10.1371/journal.pone.0080115.

6. Mohammad MK, Zhou Z, Cave M, Barve A, McClain CJ. Zinc and liver disease. Nutr Clin Pract. 2012;27(1):8-20. DOI:10.1177/0884533611433534.

7. Ayana G, Moges T, Samuel A, Asefa T, Eshetu S, Kebede A. Dietary zinc intake and its determinants among Ethiopian children 6-35 months of age. BMC Nutr. 2018;4(1):30. DOI:10.1186/s40795-018-0237-8.

8. Roohani N, Hurrell R, Kelishadi R, Schulin R. Zinc and its importance for human health: An integrative review. J Res Med Sci. 2013;18(2):14457. 
9. Gibson RS. Zinc. The missing link in combating micronutrient malnutrition in developing countries. Proc Nutr Soc. 2006;65:51-60. DOI:10.1079/PNS200547.

10. Sandström B, Almgren A, Kivistö B, Cederblad Å. Zinc absorption in humans from meals based on rye, barley, oatmeal, triticale and whole wheat. J Nutr. 1987;117(11):1898-902. DOI:10.1093/jn/117.11.1898.

11. Bailey RL, West KP Jr, Black RE. The epidemiology of global micronutrient deficiencies. Ann Nutr Metab. 2015;66(Suppl. 2):22-33. DOI:10.1159/000371618.

12. Joy EJ, Ander EL, Young SD, Black CR, Watts MJ, Chilimba AD, Chilima B, Siyame EW, Kalimbira AA, Hurst R, Fairweather-Tait SJ. Dietary mineral supplies in Africa. Physiol Plant. 2014;151(3):208-29. DOI:10.1111/ppl.12144.

13. National Statistical Office (NSO). Community Health Service Unit (CHSU), Centers for Disease Control and Prevention (CDC), Emory University. Malawi Micronutrient Survey2015-16: Key indicators Report, Atlanta, GA, USA, CHSU, CDC and Emory University. 2017.

14. Ferguson EL, Gibson RS, Thompson LU, Ounpuu S. Dietary calcium, phytate, and zinc intakes and the calcium, phytate, and zinc molar ratios of the diets of a selected group of East African children. Am J Clin Nutr. 1989;50(6):1450-56. DOI:10.1093/ajcn/50.6.1450.

15. Siyame EWP, Hurst R, Wawer AA, Young SD, Watts MJ, Broadley MR, Chilimba AC, Ander LE, Watts MJ, Chilima B, Gondwe J, Kang'ombe D, Kalimbira AA, Fairwether-Tait SJ, Bailey KB, Gibson RS. A high prevalence of zinc but not iron deficiency among women in rural Malawi: A cross-sectional study. Int J Vitam Nutr Res. 2013;83(3):176-87. DOI:10.1024/0300-9831/a000158.

16. Joy EJ, Kumssa DB, Broadley MR, Watts MJ, Young SD, Chilimba AD, Ander EL. Dietary mineral supplies in Malawi: spatial and socioeconomic assessment. BMC Nutr. 2015;1:42. DOI:10.1186/s40795-015-0036-4.

17. Tudor R, Zalewski PD, Ratnaike RN. Zinc in health and chronic disease. J Nutr Health Aging. 2005;9(1):45-51.

18. Wang Y, Jia XF, Zhang B, Wang ZH, Zhang JG, Huang FF, Su C, Ouyang YF, Zhao J, Du WW, Li L. Dietary zinc intake and its association with metabolic syndrome indicators among Chinese adults: an analysis of the China Nutritional Transition Cohort Survey. 2015. Nutrients, 2018; 10(5):572. DOI: $10.3390 /$ nu10050572.

19. National Statistical Office. Malawi Population and Housing Census 2018. Malawi: Zomba; 2019.

20. Dean AG, Sullivan KM, Soe MM. OpenEpi: Open Source Epidemiologic Statistics for Public Health, version 3.01. 2014.

21. Gibson RS, Ferguson EL. An interactive 24-hour recall for assessing the adequacy for iron and zinc intakes in developing countries; 2nd edition HarvestPlus Technical Monographs 8. Washington DC: 2008.

22. Malawi Government. MAFOODS: Malawian Food Composition Table; 1st Edition. Lilongwe, Malawi: 2019.

23. Mpulula O. Effect of home based maize processing methods on apparent iron and zinc bioavailability. MSc Thesis, University of Malawi: Bunda College. 2013.

24. Hunt J. Moving toward a plant-based diet: are iron and zinc at risk? Nutr Rev. 2002;60(5):127-34. D0I:10.1301/00296640260093788.

25. Adams CL, Hambidge H, Raboy V, Dorsch JA, Sian L, Westcott JL, Krebs NF. Zinc absorption from a low-phytic acid maize. Am J Clin Nutr. 2002;76:556-9. DOI:10.1093/ajcn/76.3.556. 